\title{
ANALISIS FRAMING TERKAIT PEMBERITAAN JOKOWI YANG MENYERANG PRIBADI PRABOWO PADA DEBAT CALON PRESIDEN \\ PUTARAN KEDUA TAHUN 2019 DALAM “mediaindonesia.com”
}

\author{
Stepanus Sitanggang, Dina Fadiyah \\ Ilmu Politik - Universitas 17 Agustus 1945 Jakarta \\ Email: stepanus.sitanggang71098@gmail.com
}

\begin{abstract}
This paper will discuss Analysis of Framing Related to the Coverage of Jokowi Who Attacked Prabowo in the Second Round of Presidential Candidates for 2019 in "mediaindonesia.com". The purposes of this paper are (1) To find out a picture of how media framing mediaindonesia.com in delivering an incident related to Jokowi who personally attacked Prabowo in the second round of Presidential candidates in 2019. (2) To find out the relationship between mediaindonesia.com and democracy in reporting of Jokowi who personally attacked Prabowo at the second round of the Presidential debate in 2019. The research used the Theory of Framing Analysis from Gamson and Modigliani. This research method used qualitative research. The results of this research explain that (1) Framing of mediaindonesia.com reporting in presenting an incident related to Jokowi who personally attacked Prabowo in the second round of Presidential candidates in 2019. (2) There was a connection between mediaindonesia.com and democracy in reporting of Jokowi on personality of Prabowo in debating the second round of the Presidential candidates in 2019. So, the conclusion of this research shows that in mediaindonesia.com reporting, it emphasizes what supports Jokowi and shows the point of view that leads to the control of the land owned by Prabowo. Mediaindonesia.com's partisanship supports the diminishing democratic values in Indonesia where the media are the fourth pillar of democracy itself.
\end{abstract}

Keywords: Framing analysis, Democracy, Presidential Debate.

\section{PENDAHULUAN}

Tulisan ini mengkaji tentang analisis framing terkait pemberitaan Jokowi yang menyerang pribadi Prabowo pada debat Calon Presiden putaran kedua tahun 2019 dalam "mediaindonesia.com" Alasan peneliti melakukan penelitian terkait analisis framing terkait pemberitaan Jokowi yang menyerang pribadi Prabowo pada debat Calon Presiden putaran kedua tahun 2019 dalam "mediaindonesia.com” ini adalah 
karena dalam empirical problem pada saat debat calon Presiden putaran kedua tahun 2019 yang lalu, Jokowi dianggap telah melanggar aturan debat pasal kedua dengan menyerang pribadi Prabowo yaitu yang berbunyi bahwa panelis dilarang untuk menyerang pribadi panelis lain nya. Dalam kegiatan tersebut, mediaindonesia.com terlihat begitu antusias dalam memberitakan kegiatan debat calon Presiden tersebut dibanding kegiatan-kegiatan lain nya, banyak pemberitaan terkait debat calon Presiden 2019 antara kedua paslon, ternyata ketika diperhatikan bahwa di setiap media online memiliki perbedaan yang cukup menarik perhatian massa, perbedaan tersebut dapat dilihat pada berita salah satu pasangan calon Presiden yang dilakukan oleh mediaindonesia terhadap calon Presiden. Hal ini pun menarik untuk diteliti, demi mengetahui lebih dalam lagi bagaimana sebenarnya hubungan antara mediaindonesia.com dan pasangan calon Presiden 2019, apakah sebenarnya memiliki hubungan tersendiri atau hanya kebetulan saja.

Debat merupakan baik atau buruknya suatu usulan tertentu yang didukung oleh satu pihak yang disebut pendukung atau afirmatif, dan ditolak, disangkal oleh pihak lain yang disebut peyangkal atau negatif (Sujinah 2017:115). Pada pemilihan Presiden 2019, KPU menyelengarakan debat yang diikuti oleh dua kandidat calon Presiden dan wakil Presiden yaitu Jokowi-Ma'ruf Amin dan Prabowo-Sandiaga Uno, yang diselengarakan dengan lima kali sesi debat yang dibagi dengan sesi calon Presiden, calon Wakil Presiden, dan pasangan kandidat Presiden dan wakil Presiden. Pada saat debat, KPU pun memiliki aturan sendiri agar pelaksanaan debat dapat berlangsung dengan hikmat dan lancar. Tapi sayang aturan yang telah di sepakati ini pun tidak indahkan oleh Jokowi yang sebagai calon Presiden, khusus nya pada aturan yang ke-2 yaitu yang berisikan pertanyaan kandidat dibatasi seputar visi-misi diberikan waktu berbicara dan tidak diperkenankan menyerang personal. Jokowi dinilai menyerang personal dengan mengatakan "Kita tidak berikan kepada yang gede-gede. Saya tahu Pak Prabowo memiliki lahan yang sangat luas di Kalimantan Timur sebesar 220.000 hektar juga di Aceh Tengah 120.000 hektar. Saya hanya ingin sampaikan bahwa pembagian-pembagian seperti ini tidak dilakukan masa pemerintahan saya" kata 
Jokowi dalam debat hari Minggu (17/2/2019). (Sumber: https://tirto.id/dianggapserang-pribadi-prabowo-jokowi-dilaporkan-ke-bawaslu-dhiP, diakses pada tanggal 21 Januari 2020 pukul 15:07 WIB).

Seiring berkembangnya teknologi, maka semakin berkembang juga beritaberita yang ada di media online, hal ini pun menjadi daya tarik tersendiri yakni terkait berita debat calon Presiden 2019 yang dianggap ada indikasi non profesionalitas media online dalam memberitakan terkait salah satu paslon dalam debat putaran kedua calon Presiden 2019. Hal ini membuktikan bahwa media online sebagai alat dalam suatu proses berjalanya demokrasi di Indonesia sudah mulai luntur dan dipolitisasi.

Hal ini dikarenakan media online sendiri merupakan salah satu alat politik dalam menjangkau berbagai masyarakat dan memiliki kekuatan dalam pembentukan opini publik terhadap khalayak. Pada saat pemilihan umum yang terdiri dari pemilihan Presiden, pemilihan Kepala daerah, hingga pemilihan Legislatif, yang merupakan salah satu suatu ajang pesta demokrasi yang dilakukan di setiap 5 tahun sekali, khususnya pada pemilihan Presiden kegiatan ini dimulai semenjak di ubahnya undang-undang pemilu terkait pemilihan umum. Hal ini memperjelas bahwa adanya suatu kemajuan dalam demokrasi Indonesia. Kegiatan pemilihan umum ini biasanya di isi oleh suatu rangkaian kegiatan yang biasa kita sebut dengan debat, hal ini lah yang menjadi suatu kesempatan bagi para calon Presiden atau pun Kepala daerah dalam menunjukan visi misi, program kerja maupun strateginya dalam memenangkan pemilihan umum tersebut.

Secara teoritical problem terdapat penelitian terdahulu yang mengatakan bahwa salah satu media online yaitu okezone dan detik.com melakukan keberpihakan melalui dalam framing di pemberitaanya pada pemilihan Presiden Indonesia 2014 adanya keberpihakan terhadap salah satu pasangan calonya masing-masing. Okezone berpihak pada Prabowo sedangkan detik.com berpihak pada Jokowi Yang seharusnya media online sendiri dintuntut untuk menegakan sebuah independensi sebagai salah satu sarana pelaksana pilar dalam berjalanya demokrasi di Indonesia.. 
Kenapa periswita ini diberitakan, sementara peristiwa itu tidak diberitakan? Kenapa sisi ini yang diberitakan sementara sisi yang itu luput dalam pemberitaan? Kenapa aspek yang ini yang ditonjolkan oleh media, sementara aspek yang itu dihilangkan dalam pemberitaan? Kenapa bagian yang ini yang ditekankan oleh media, sedangkan bagian yang itu dikaburkan? Semua pertanyaan tersebut mengarah dalam konsep yang disebut sebagai framing (Eriyanto 2002:2).

Framing juga adalah sebuah cara bagaimana peristiwa disajikan oleh media. Penyajian tersebut dilakukan dengan menekankan bagian tertentu, menonjolkan aspek tertentu dan membesarkan cara bercerita tertentu dari suatu realitas. Media menghubungkan dan menonjolkan peristiwa sehingga makna dari peristiwa tersebut lebih mudah diingat oleh khalayak. Karenanya, seperti yang dikatakan Frank D. Durham, framing membuat dunia lebih diketahui dan lebih dimengerti. Realitas yang kompleks dipahami dan disederhanakan dalam kategori tertentu. Menurut pandangan subjektif, realitas sosial adalah suatu kondisi yang cair dan mudah berubah melalui interaksi manusia dalam kehidupan sehari-hari (Mulyana, 2006: 34).

Cukup disayangkan jika luntur demokrasi dan hak masyarakat yang seharusnya mendapatkan informasi yang benar dan terjamin harus dicederai oleh kepentingankepentingan politik, sehingga nilai pendidikan, hiburan, analisis dan pengetahuan harus sirnah begitu saja, apalagi ditengah keberlangsungan pemilihan Presiden tahun 2019 ini, perhelatan politik yang begitu memanas dan ketat, dalam hal ini mediaindonesia.com dalam menuai opini agar masyarakat berpihak pada salah satu pasangan calon Presiden dan memilih terhadap calon tersebut karena simpati akibat membaca pemberitaan-pemberitaan yang ada di mediaindonesia.com.

TEORI ANALISIS FRAMING : WILLIAM A. GAMSON DAN MODIGLIANI 
Dalam penelitian skripsi ini peneliti menggunakan analisis framing sebagai landasan utama. Analisi framing merupakan analisa yang dipakai untuk melihat bagaimana media mengontruksi realitas (Eriyanto 2002:11). Analis framing memiliki ciri katakter yang berbeda dengan analisis isi kuantitatif. Dalam analisis framing, yang menjadi fokus perhatian adalah pembentukan pesan dari teks. Framing, terutama melihat bagaimana pesan/peristiwa dikontruksikan oleh media. Bagaimana seorang wartawan mengontruksikan suatu peristiwa dan memberitakan kepada para khalayak.

Analisis framing digunakan untuk mengetahui bagaimana realita dikontruksikan oleh media, dalam kasus ini khususnya mediaindonesia.com. Untuk mengetahui dengan teknik dan cara apa untuk menunjukan suatu peristiwa agar terlihat menonjol di khalayak umum. Mulai dari adanya bagian-bagian berita yang sengaja disembunyikan atau dihilangkan. Secara sederhana analisis framing dapat digambarkan sebagai analisi untuk mengetahui bagaimana realitas (peristiwa, aktor, kelompok, atau apa saja) dibingkai oleh media. Pembingkaian tesebut tentu saja melalui proses kontruksi (Eriyanto 2002:11). Analisis framing ini sebenarnya bisa merubah pandangan seseorang terkait suatu permasalahan yang ada, sehingga penikmat dari berita tersebut merasa percaya dan mengikuti apa yang telah di berita kan.

Tabel 2.2

Perangkat Analisis Framing Gamson Dan Modigliani

\begin{tabular}{|c|c|}
\hline $\begin{array}{c}\text { Framing Device } \\
\text { (Perangkat Framing) }\end{array}$ & $\begin{array}{c}\text { Reasoning device } \\
\text { (Perangkat Penalaran) }\end{array}$ \\
\hline Metaphors & $\begin{array}{c}\text { Roots } \\
\text { (Pebab akibat) }\end{array}$ \\
\hline Catchphrases & Appealtoprinciple \\
(Frase yang menraik, kontras, & (Premis dasar, klaim moral) \\
\hline
\end{tabular}

64 


\begin{tabular}{|c|c|}
\hline $\begin{array}{l}\text { menonjolkan dalam suatu wacana, ini } \\
\text { umumnya berupa jargon atau slogan) }\end{array}$ & \\
\hline $\begin{array}{c}\text { Exemplar } \\
\text { (Mengaitkan bingkai dengan contoh, } \\
\text { uraian (bisa teori, perbandingan) yang } \\
\text { mempejelas bingkai) }\end{array}$ & $\begin{array}{c}\text { Consequences } \\
\text { (Efek atau konsekuensi yang didapat dari } \\
\text { bingkai) }\end{array}$ \\
\hline $\begin{array}{c}\text { Depictions } \\
\text { (Penggambaran isu bersifat konotatif, } \\
\text { berupa kosakata) }\end{array}$ & \\
\hline $\begin{array}{c}\text { Visual images } \\
\text { (Gambar, grafik, citra pendukung pesan } \\
\text { yang ingin disampaikan) }\end{array}$ & \\
\hline
\end{tabular}

Sumber: Eriyanto, Analisis Framing Kontruksi, Ideologi, dan Politik Media, (Yogyakarta:YKiS Group,2012), hlm.260)

Beberapa pengertian dari Analisis Framing model Gamson dan Modigliani yaitu:

\section{A. Framing Devices}

1. Metaphors : Sebagai cara memindah makna dengan merealisasikan dua fakta melalui analogi atau memaknai kiasan dengan menggunakan kata-kata seperti, ibarat, bak, sebagai, umpama, laksana.

2. Catchphrases : Bentukan kata atau frase cerminan fakta yang merujuk pada pemikiran atau semangat tertentu, menarik, kontras, menonjolkan dalam suatu wacana. Ini umumnya berupa jargon atau slogan.

3. Exemplar : Mengemas fakta tertentu secara mendalam agar satu sisi memiliki bobot makna, lebih untuk dijadikan rujukan atau pelajaran. Posisinya menjadi pelengkap bingkai inti dalam kesatuan berita untuk membenarkan perspektif.

4. Depictions : Pengambaran fakta dengan memakai kata, istilah, kalimat konotatif 
agar khalayak terarah ke citra tertentu.

5. Visual images : Pemakaian foto, diagram, grafik, tabel, kartun, dan sejenisnya untuk mengepresikan kesan, misalnya perhatian atau penolakan, dibesarbesarkan,ditebalkan, dimiringkan, serta pemakaian warna.

B. Reasoning devices

1. Roots : Pembenaran isu dengan menghubungkan suatu objek atau lebih yang dianggap menjadi sebeb timbulnya atau terjadinya hal yang lain. Tujuanya membenarkan penyimpulan fakta berdasarkan hubungan sebab-akibat yang digambarkan atau dibeberkan.

2.Appeal to principle : Pemikiran, prinisp, klaim moral, sebagai argumentasi pembenar membangun berita, berupa pepatah, cerita rakyat, mitos, doktrin, ajaran, dan sejenisnya.

3. Consequences : Efek atau pengaruh yang didapatkan dari sebuah bingkai berita.

Model diatas merupakan model analisis framing yang secara umum teori ini Gamson dan Modigliani memahami wacana media sebagai satu gugusan perspektif interpretasi saat mengkonstruksi dan memberi makna suatu isu. Analisis framing, melihat skema media ketika mengontruksikan pesan yang disampaikan dan memahami pesan yang dia terima, serta bagaimana sikap editoral Media online yang ada di Indonesia terhadap pemilihan Presiden Indonesia 2019. Dibalik kebebasan pers dalam mengemas suatu berita dengan mengunakan bahasa dan fakta yang digunakan membuat rentan adanya penyalahgunaan kekuasaan, hal yang membuat beberapa media tonline itu akan kehilangan citra baik dimata masyarakat jika masyarakat sadar akan penyalagunaan kekuasaan tersebut.

Konstruksi realitas pada dasarnya menceritakan peristiwa apapun yang terjadi, maka tugas utamanya mengonstruksikan berbagai realita yang akan ditayangkan, disusun hingga menjadi wacana yang penuh dengan makna, unsur utama dari semuanya yaitu bahasa, dalam pemilihan bahasa harus disesuaikan dengan format

66 
narasi yang akan dibuat. Bahasa itu bisa menjelaskan gambaran dari sebuah peristiwa, dan melalui bahasa dapat menentukan citra seorang seseorang diberita-berita politik.

\section{ANALISIS mediaindonesia.com MELAKUKAN FRAMING PEMBERITAAN TERKAIT PERMASALAHAN JOKOWI YANG MENYERANG PRIBADI PRABOWO DI DEBAT CALON PRESIDEN PUTARAN KEDUA TAHUN 2019.}

Mediaindonesia.com selama debat calon Presiden Indonesia 2019 telah mengeluarkan berita kurang lebih 20 berita mengenai antara Jokowi maupun Prabowo. Berita tersebut berjangka waktu dari 23 September 2018 hingga 13 April 2019 dan yang menjadi bahan untuk dianalisis terdiri dari 6 berita.

Element inti berita ini, mediaindonesia.com adalah bahwa konflik antara kubu Jokowi vs Prabowo, ini berawal dari kata-kata Jokowi saat sesi debat pemlihan Presiden kedua, yang dinilai melanggar aturan yang ditetapkan panitia pada saat debat yaitu argument debat yang menyerang kandidat lawan. Jokowi menyerang Pribadi Prabowo terkait penguasaan lahan di Indonesia. Hal itu pun terlihat jelas dalam berita tersebut.

1. Methapors (Perumpamaan atau pengandaian) yang dihadirkan oleh mediaindonesia.com adalah sebagai berikut:

Gambar 4.2.2

67 


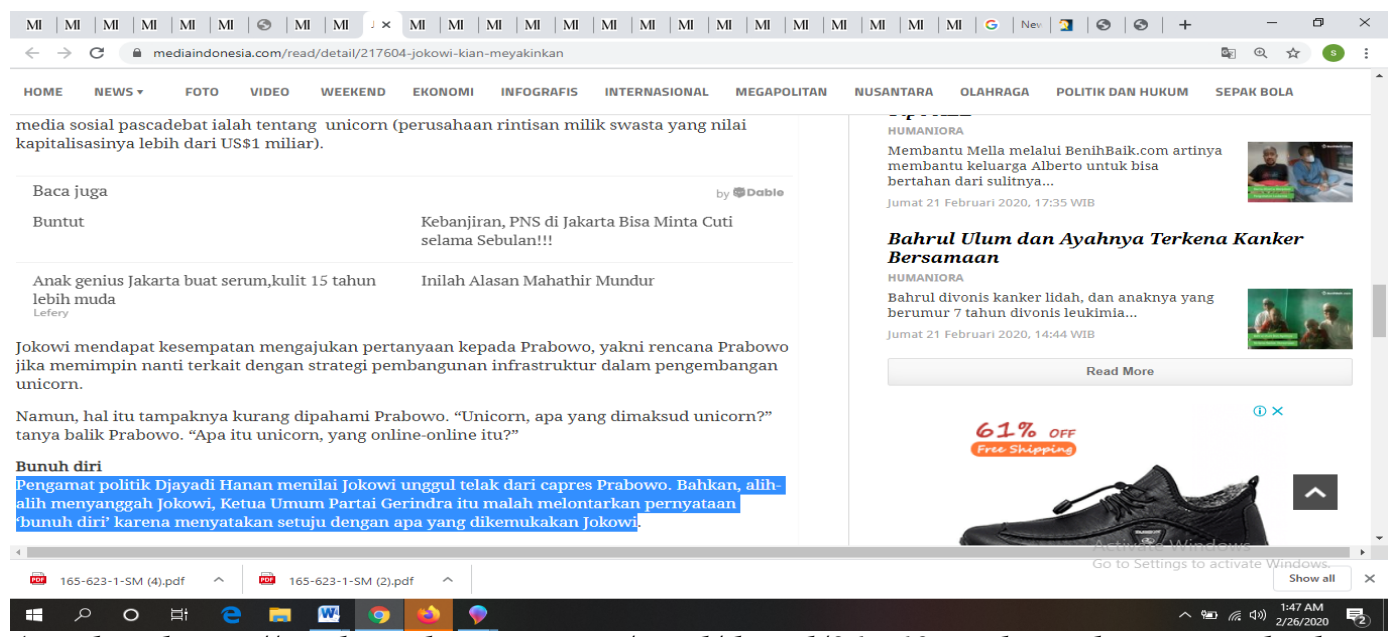

(sumber:https://mediaindonesia.com/read/detail/217604-jokowi-kian meyakinkan, diakses pada 10 Januari 2020 pukul 13:10 WIB)

Berita di atas tersebut adalah jelas bahwa perumpamaan atau pengandaian yang ditekankan oleh mediaindonesia.com dibungkus dalam pernyataan:

"menurut Pengamat politik Djayadi Hanan Ketua Umum Partai Gerindra itu malah melontarkan pernyataan 'bunuh diri' karena menyatakan setuju dengan apa yang dikemukakan Jokowi”.

Disini dijelaskan bahwa Prabowo sebagai lawan politik dari Jokowi dalam debat putaran kedua calon Presiden 2019 menanggapi terkait permasalahan yang dianggap Jokowi yang menyerang terhadap dirinya pada saat debat putaran kedua berlangsung dan ironinya, Prabowo malah setuju dengan pernyataan Jokowi tersebut yang mengatakan Prabowo tersandung permasalahan penguasaan lahan. Sebagai seorang calon Presiden, Prabowo seharusnya tidak memiliki masalah terkait pernguasaan lahan yang sampai terdengar oleh masyarakat luas. Pengunaan kata bunuh diri yang digunakan oleh mediaindonesia.com dalam hal ini membuat seakan Prabowo telah mengkritik atau menjelekan diri nya sendiri terkait permasalahan tanah ini.

2. Catchphrases (jargon atau slogan) ini adalah biasanya kata-kata yang menonjol dalam suatu wacana. Catchphrases adalah sebagai berikut:

\section{Gambar 4.2.3}

68 


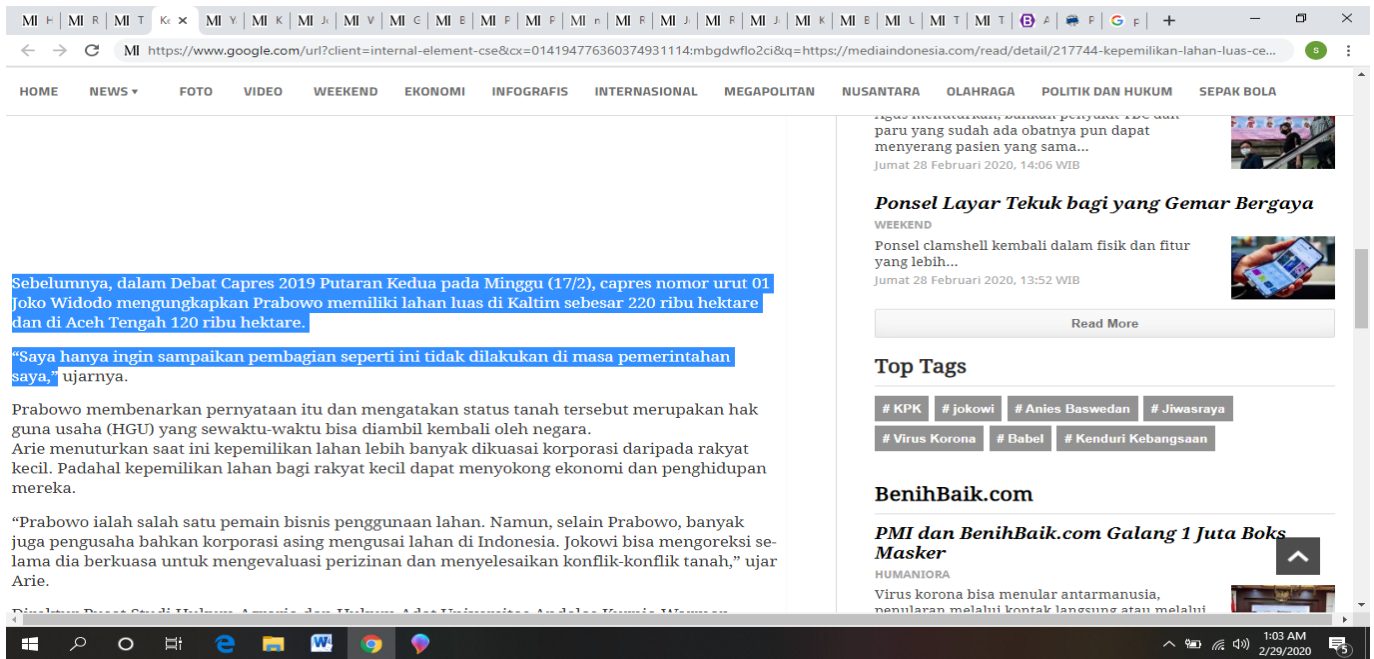

(sumber:https://mediaindonesia.com/read/detail/217744-kepemilikan-lahan-luascerminkan-ketimpangan.html, diakses pada 10 Januari 2020 pukul 13:20 WIB)

Berita di atas tersebut adalah jelas bahwa jargon atau slogan yang di tekankan oleh mediaindonesia.com dibungkus dalam pernyataan:

\section{"Saya hanya ingin sampaikan pembagian seperti ini tidak dilakukan di} masa pemerintahan saya"

Disini dijelaskan bahwa Jokowi sebagai calon Presiden petahana yang pernah menjabat sebagai Presiden, ingin membuat simpati masyarakat dengan membongkar kepemilikan tanah yang dimiliki oleh Prabowo di Aceh dan di Kalimantan, dengan pengunaan jargon diatas, mediaindonesia.com ingin menekankan kepada masyarakat bahwasanya semasa dirinya menjabat sebagai Presiden tidak pernah melakukan permasalahan terkait pembagian tanah dalam jumlah besar kepada pengusaha seperti hal nya yang dimiliki oleh Prabowo. Sehingga dalam arti kalimat ini pesan yang disampaikan bahwa Jokowi tidak mendukung ketimpangan lahan kepada masyarakat kecil.

3. Exemplar yaitu Perbandingan dalam memperjelas bingkai dalam sebuah wacana. Perbandingan dalam mediaindonesia.com adalah sebagai berikut

\section{Gambar 4.2.4}

69 


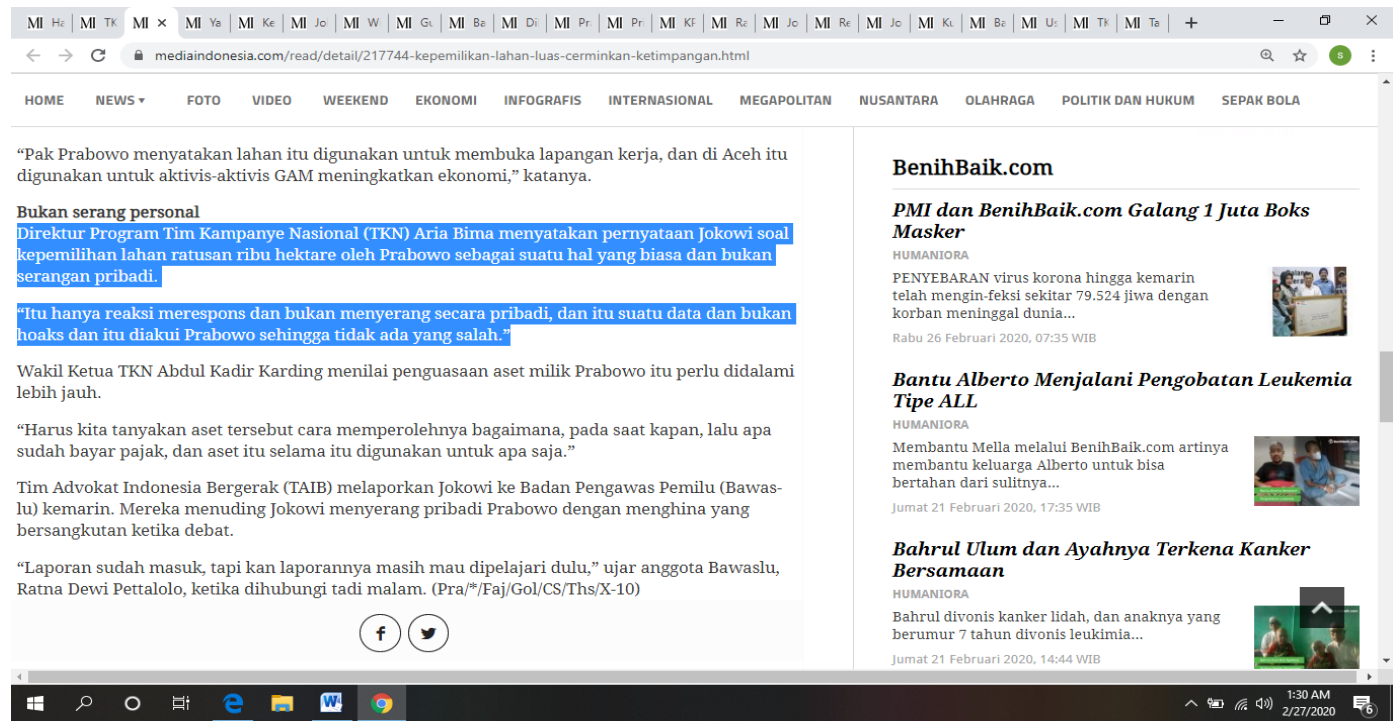

(sumber:https://mediaindonesia.com/read/detail/217744-kepemilikan-lahan-luascerminkan-ketimpangan.html, diakses pada 10 Januari 2020 pukul 13:45 WIB)

Perbandingan dalam memperjelas bingkai dalam sebuah wacana yang ditekankan oleh mediaindonesia.com dibungkus dalam pernyataan

\begin{abstract}
"Direktur Program Tim Kampanye Nasional (TKN) Aria Bima menyatakan pernyataan Jokowi soal kepemilihan lahan ratusan ribu hektare oleh Prabowo sebagai suatu hal yang biasa dan bukan serangan pribadi. "Itu hanya reaksi merespons dan bukan menyerang secara pribadi, dan itu suatu data dan bukan hoaks dan itu diakui Prabowo sehingga tidak ada yang salah."
\end{abstract}

Disini dijelaskan bahwa Jokowi dalam pernyataanya soal kepemilikan lahan ratusan ribu hektar bukan termasuk serangan pribadi, melainkan itu hanya seuatu reaksi merespon dan suatu data serta diakui oleh Prabowo sebagai yang mengunakan lahan tersebut. Kata-Kata ini lah menjadi tameng sebagai pembelaan bahwa Jokowi tidak melakukan pelanggaran debat yang menyerang pribadi Prabowo. Dari kalimat ini mediaindonesia.com ingin menyampaikan pesan bahwasanya Jokowi tidak melakukan kesalahan dan yang dilakukan Jokowi itu bukan menyerang pribadi Prabowo, tidak seperti apa yang dituduhkan kepada Jokowi selama ini. 
4. Depiction adalah Sebuah penggambaran yang umumnya berupa kosakata, leksion untuk melabeli sesuatu, biasanya istilah-istilah yang digunakan adalah istilah-istilah sindiran atau yang tidak sesuai dengan kenyataan yang ada seperti pemberitaan berikut ini:

\section{Gambar 4.2.5}

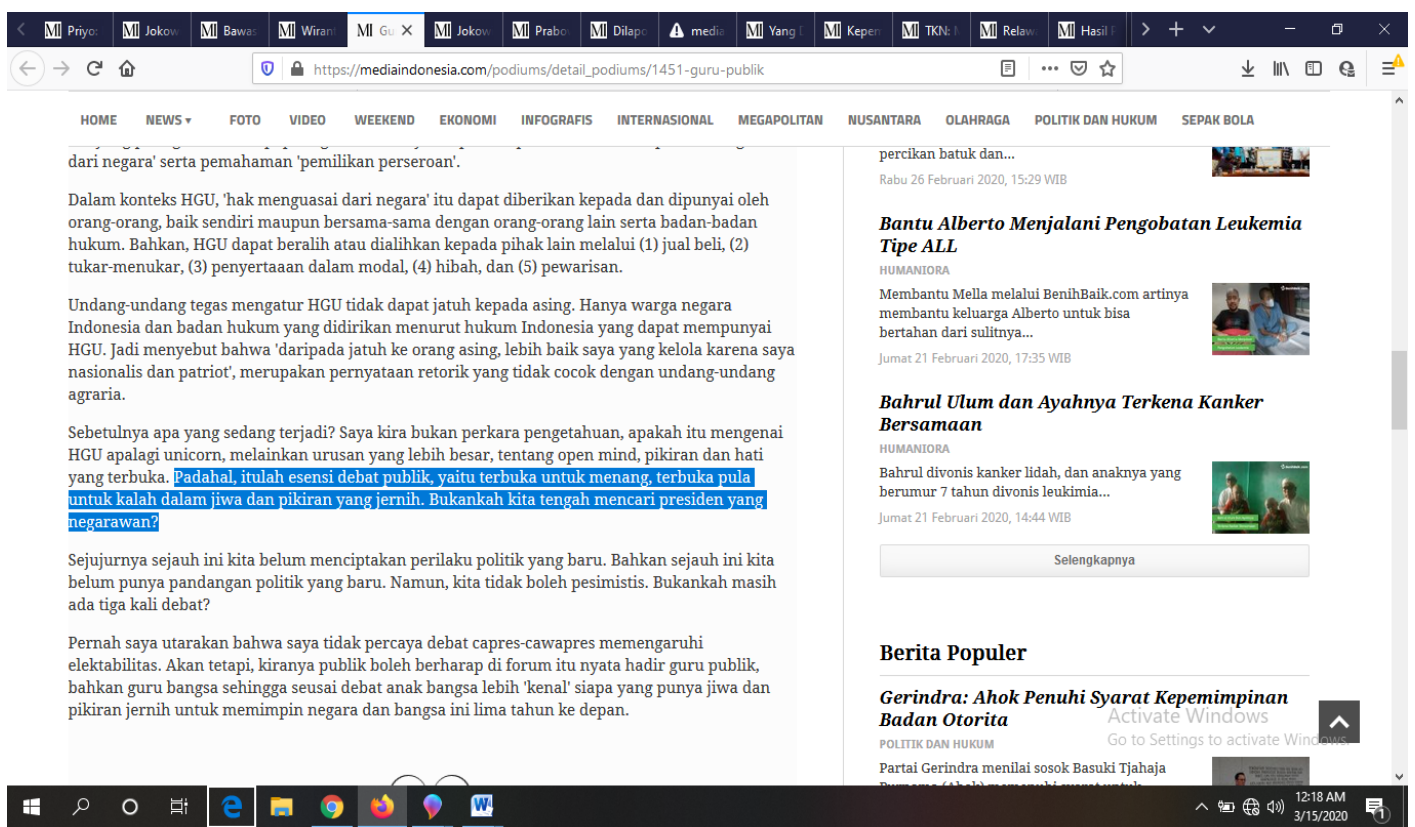

(sumber:https://mediaindonesia.com/podiums/detail_podiums/1451-guru-publik, diakses pada tanggal diakses pada 10 Januari 2020 pukul 13:40 WIB).

Berita diatas tersebut jelas (Penggambaran isu bersifat konotatif, berupa kosakata) yang di tekankan oleh mediaindonesia.com dibungkus dalam pernyataan:

"Padahal, itulah esensi debat publik, yaitu terbuka untuk menang, terbuka pula untuk kalah dalam jiwa dan pikiran yang jernih. Bukankah kita tengah mencari presiden yang negarawan?"

Dari berita diatas mengisyaratkan bahwa debat calom Presiden seharusnya terbuka untuk kalah maupun menang dengan jiwa dan pikiran yang jernih, bukan mengatakan pernyataan retorik dan melaporkan lawan politiknya karna masyarakat mencari Presiden yang negarawan. Dari kalimat tersebut mediaindonesia.com ingin 
menekankan pengambaran isu konotatif nya yaitu jiwa dan pikiran yang jernih sebagai gambaran bahwa jiwa dan pikiran yang positif dan professional.

5. Visual image yaitu Berupa pemakaian foto, diagram, grafik, tabel, kartun, dan sejenisnya untuk mengepresikan kesan, misalnya perhatian atau penolakan, dibesarbesarkan, di pertebal, di miringkan, dan lain sebagainya.

\section{Gambar 4.2.6}

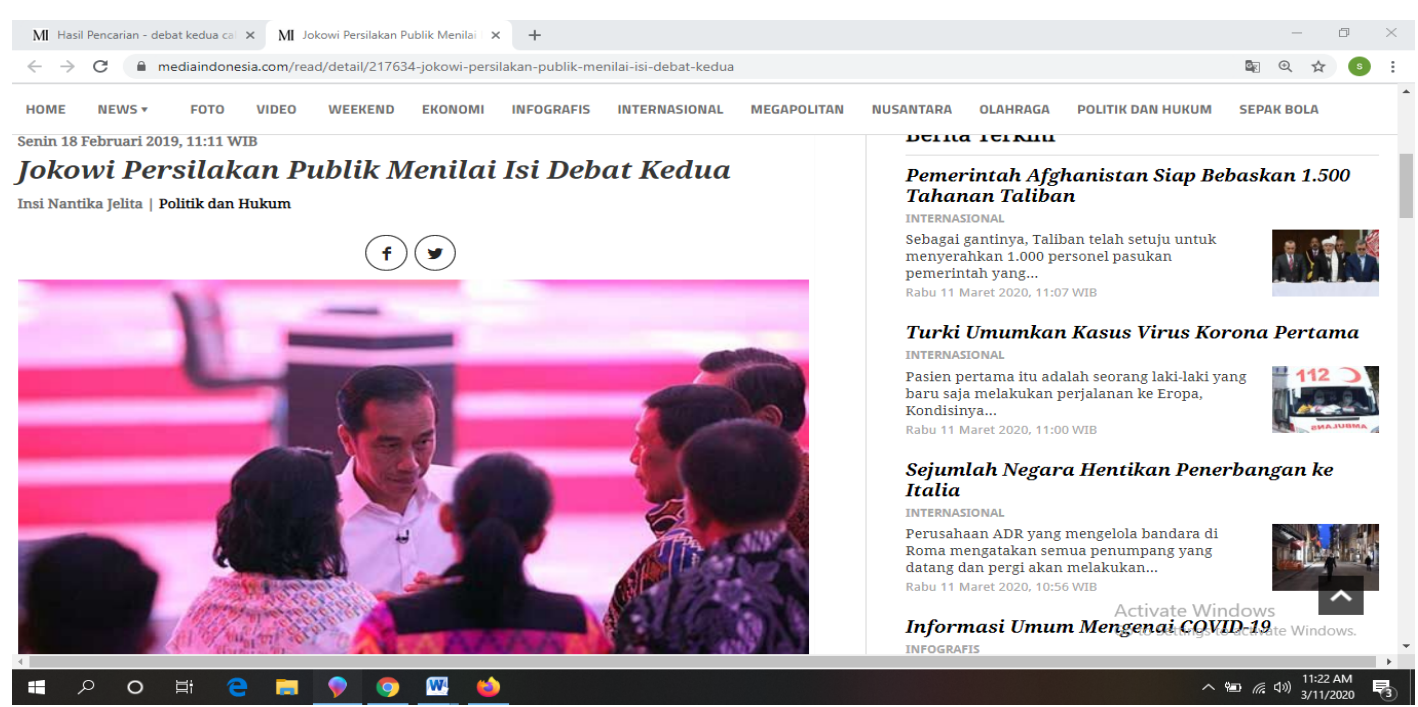

(https://mediaindonesia.com/read/detail/217634-jokowi-persilakan-publik menilaiisi-debat-kedua, diakses pada 10 Januari 2020 pukul 13:57 WIB)

Dari gambar tersebut dapat dijelaskan bahwa ekspresi yang tergambar dalam raut wajah nya bahwa Jokowi tegas dan yakin dan gaya tubuh Jokowi mengisyaratkan bahwa Jokowi ingin menjelaskan kepada team pemenanganya yaitu ada Luhut Binsar, Wiranto, Grace Natalis, dan lainya yang terdapat didalam gambar tersebut bahwa Jokowi tidak menyerang personal Prabowo pada saat debat berlangsung.

Perangkat penalaran adalah Pemikiran yang dikembangkan oleh mediaindonesia.com dalam setiap pemberitaan nya didukung dengan beberapa perangkat penalaran untuk menekan kepada pembaca berita bahwa berita yang disampaikan adalah benar. 
1. Root adalah Analisis kausal yang biasanya adalah unsur sebab akibat. Berita nya sebagai berikut:

\section{Gambar 4.2.7}

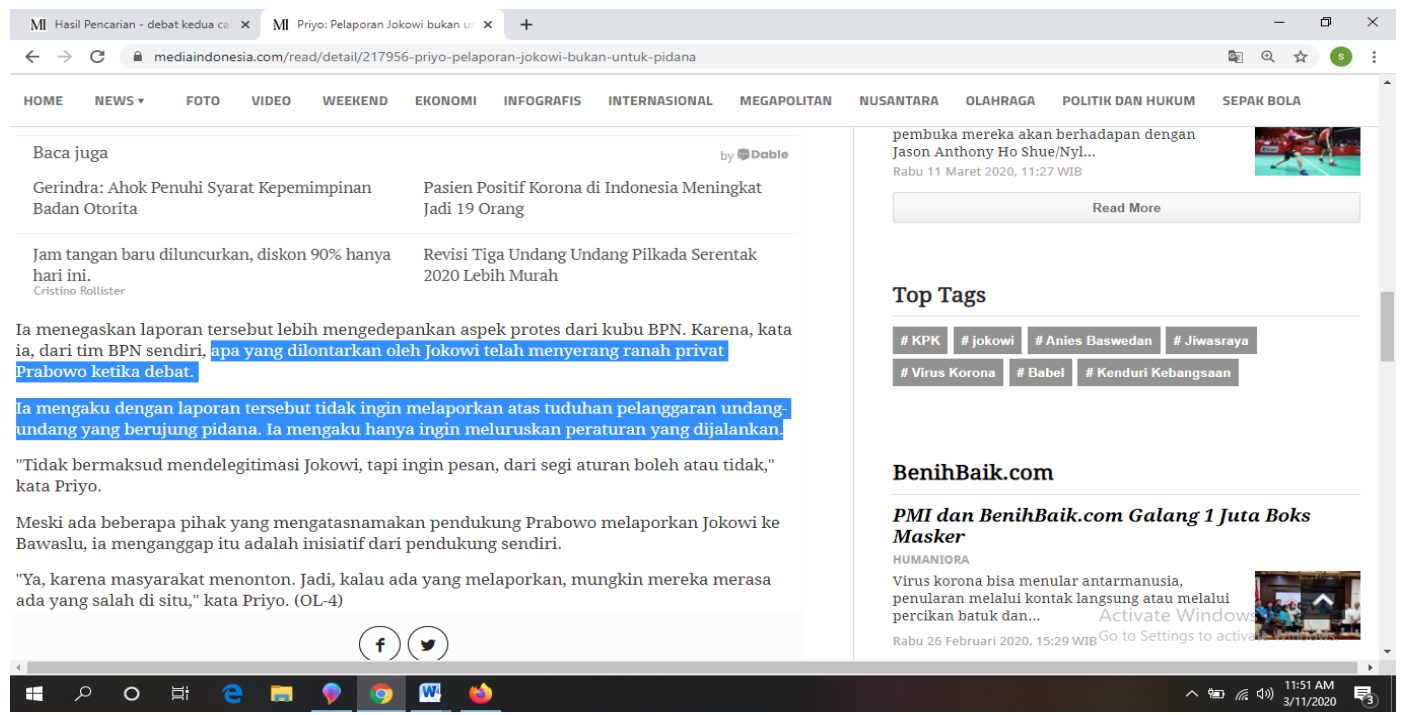

(sumber:https://mediaindonesia.com/read/detail/217956-priyo-pelaporan-jokowi-bukanuntuk-pidana, diakses pada 10 Januari 2020 pukul 14:11 WIB)

Berita diatas tersebut jelas analisis kausal yang biasanya adalah unsur sebab akibat yang di tekankan oleh mediaindonesia.com dibungkus dalam pernyataan:

"Apa yang dilontarkan oleh Jokowi telah menyerang ranah privat Prabowo ketika debat."

"Ia mengaku dengan laporan tersebut tidak ingin melaporkan atas tuduhan pelanggaran undang-undang yang berujung pidana. Ia mengaku hanya ingin meluruskan peraturan yang dijalankan."

Dari berita diatas jelas bahwa Badan Pemenangan Nasional (BPN) Prabowo-Sandi mereka menilai apa yang dilontarkan oleh Jokowi telah menyerang ranah privat Prabowo ketika debat Dan Badan Pemenangan Nasional (BPN) melaporkan Jokowi tetapi tidak untuk tuduhan pelanggaran pidana Tetapi hanya untuk meluruskan peraturan yang dijalankan. Dari sebab-akibat tersebut mediaindoesia.com ingin menekankan bahwa sebab karna apa yang dilakukan Jokowi telah menyerang ranah privat Prabowo ketika debat dan akibatnya team 
Badan Pemenangan Nasional (BPN) melaporkan tindakan Jokowi tersebut kepada Bawaslu untuk meluruskan peraturan yang dijalankan.

2. Appeals to principle adalah premis dasar atau klaim-klaim moral seperti dalam pemberitaan berikut:

\section{Gambar 4.2.8}

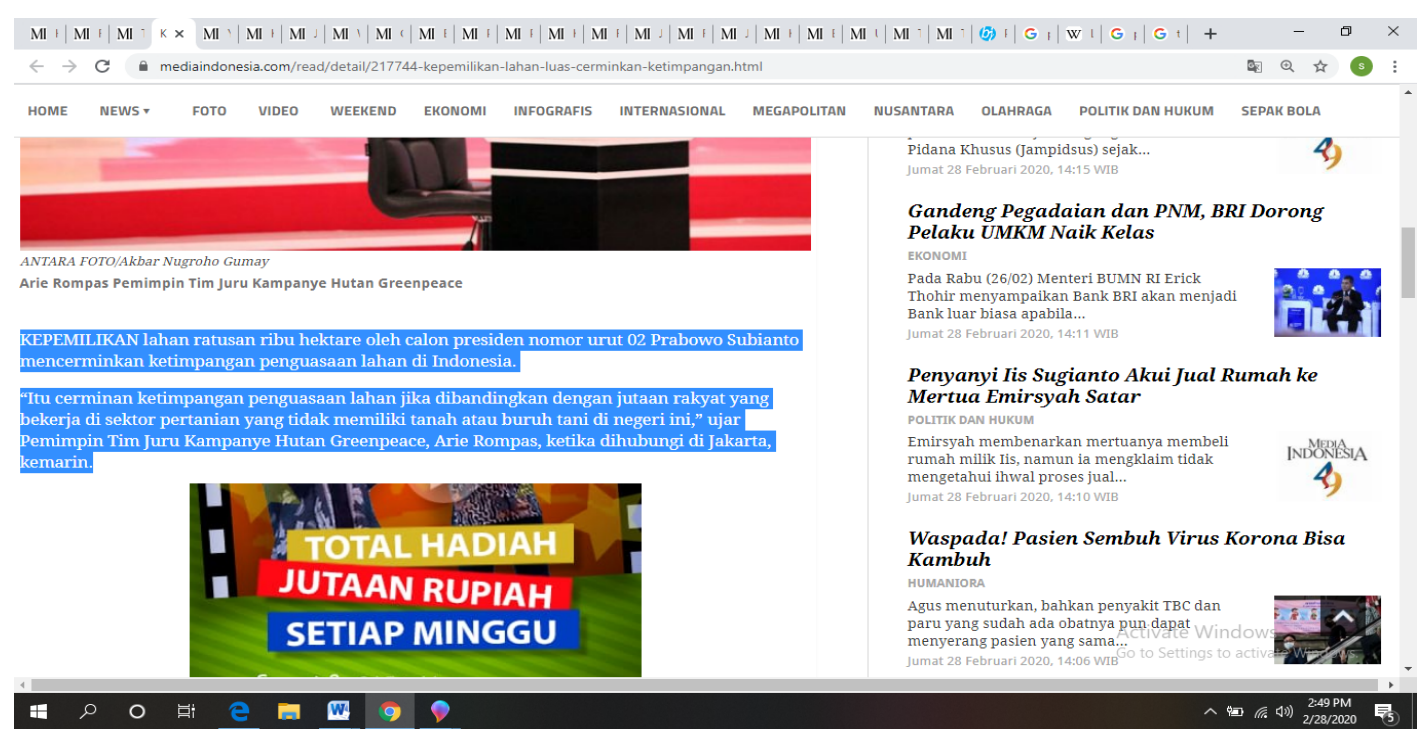

(sumber:https://mediaindonesia.com/read/detail/217744-kepemilikan-lahan-luascerminkan-ketimpangan.html, diakses pada 10 Januari 2020 pukul 14:15 WIB)

Dari berita diatas jelas bahwa klaim-klaim moral yang ditekankan oleh mendiaindonesia.com dibungkus dalam pernyataan:

"Pemimpin Tim Juru Kampanye Hutan Greenpeace, Arie Rompas "KEPEMILIKAN lahan ratusan ribu hektare oleh calon presiden nomor urut 02 Prabowo Subianto mencerminkan ketimpangan penguasaan lahan di Indonesia."

"Itu cerminan ketimpangan penguasaan lahan jika dibandingkan dengan jutaan rakyat yang bekerja di sektor pertanian yang tidak memiliki tanah atau buruh tani di negeri ini"

Dari berita diatas menjelaskan bahwa mediaindonesia.com ingin menekankan Prabowo sebagai calon Presiden tidak menunjukan sebagai tokoh nasionalisme yang berpihak kepada rakyat melainkan melakukan ketimpangan penguasaan lahan di Indonesia. 
Karna jika dilihat dari kondisi saat ini ada jutaan masyarakat yang masih bekerja di sektor pertanian tetapi tidak memiliki tanah, hanya sebagai buruh tani saja. Padahal kepemilikan lahan bagi rakyat kecil dapat menyokong ekonomi dan kehidupan mereka.

3. Conseques atau konsekuensi yang dihadirkan mediaindonesia.com dalam pemberitaan nya yaitu:

\section{Gambar 4.2.9}

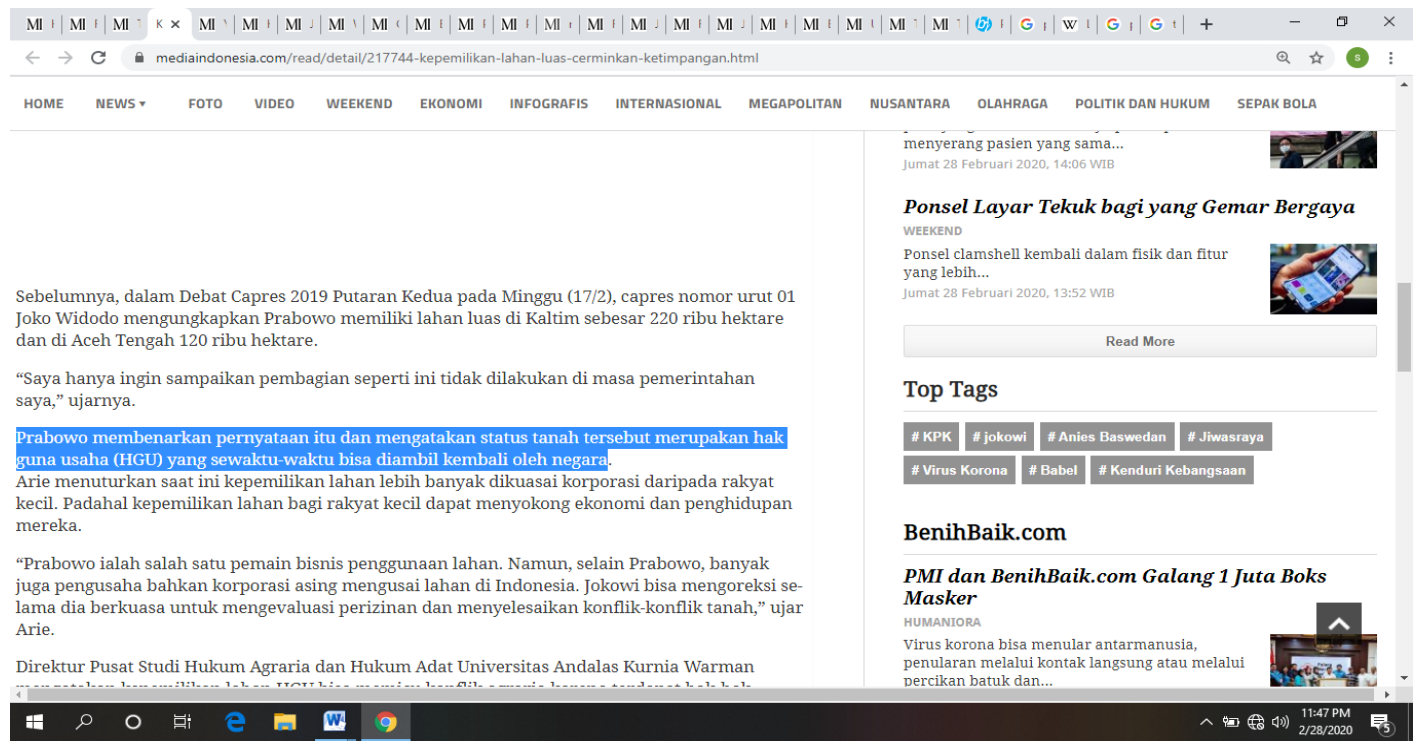

(Sumber:https://mediaindonesia.com/read/detail/217744-kepemilikan-lahan-luascerminkan-ketimpangan.html, diakses pada 10 Januari 2020 pukul 14:33 WIB)

Dari berita diatas terrsebut jelas konsekuensi yang ditekankan oleh mediaindonesia.com dibungkus dalam pernyataan:

"Prabowo membenarkan pernyataan itu dan mengatakan status tanah tersebut merupakan hak guna usaha (HGU) yang sewaktu-waktu bisa diambil kembali oleh negara."

Disini dijelaskan bahwa terdapat satu berita diatas yang mengatakan Prabowo membenarkan pernyataan Jokowi, terkait permasalahan penguasaan kepemilikan lahan yang dimiliki oleh Prabowo. Dan mengatakan itu hanya hak guna usaha yang sewaktuwaktu bisa diambil oleh negara. Sebelumnya masyarakat mengetahui bahwa apa yang 
dikatakan Jokowi dianggap melakukan pelanggaran dari aturan debat kedua yang menilai Jokowi menyerang pribadi Prabowo, karna telah membongkar kepemilikan lahan dari Prabowo, padahal yang dimiliki oleh adalah hak guna usaha jadi bukan lah kepemilikan Prabowo jadi tidak bisa dikatakan menyerang Pribadi. Tetapi walaupun hak guna usaha, bisa dikatakan cukup melakukan ketimpangan akibat terlalu banyak yang digunakan dan bisa menimbulkan konflik agrarian karena hak-hak rakyat tidak dapat terpenuhi dari pengalihan tanah rakyat ke tanah negara lalu menjadi hak guna usaha bagi pengusaha seperti Prabowo. Dari berita diatas terrsebut jelas konsekuensi yang ditekankan oleh mediaindonesia.com dibungkus dalam pernyataan:

"Prabowo membenarkan pernyataan itu dan mengatakan status tanah tersebut merupakan hak guna usaha (HGU) yang sewaktu-waktu bisa diambil kembali oleh negara."

Disini dijelaskan bahwa terdapat satu berita diatas yang mengatakan Prabowo membenarkan pernyataan Jokowi, terkait permasalahan penguasaan kepemilikan lahan yang dimiliki oleh Prabowo. Sebelumnya masyarakat mengetahui bahwa apa yang dikatakan Jokowi dianggap melakukan pelanggaran dari aturan debat kedua yang menilai Jokowi menyerang pribadi Prabowo, karna telah membongkar kepemilikan lahan dari Prabowo, padahal yang dimiliki oleh adalah hak guna usaha jadi bukan lah kepemilikan Prabowo jadi tidak bisa dikatakan menyerang Pribadi.

Dalam framing yang dilakukan oleh mediaindonesia.com terkait pemberitaan Jokowi yang menyerang pribadi prabowo pada debat calon Presiden putaran kedua tahun 2019 ini ternyata memiliki dampak dan pengaruh terhadap khalayak, setiap pemberitaanya dapat dianalisis adanya kecenderungan keberpihakan terhadap salah satu pasangan calon Presiden, hal ini pun diperkuat oleh hasil wawancara dan data dilapangan untuk mengetahui sistem framing dan pandangan mediaindonesia.com terhadap calon Presiden dalam pemberitaan tersebut.

Media online pada masa modern ini kini menjadi sesuatu yang dibutuhkan oleh masyarakat, dengan peran yang sangat vital yaitu dapat menyampaikan informasi 
kepada seluruh penjuru masyarakat. Informasi yang dibuat pun beragam, mulai dari ekonomi, sosial, buadaya dan politik. Keberadaan media dalam menyampaikan informasi terkait politik sangat penting apalagi di saat suana pemilu, kebaradaan media menjadi sebuah keharusan bagi masyarakat untuk mengetahui aktifitas maupun berita terkait calon pemimpin yang akan dipilihnya. Karna hal itu masyarakat perlu memilih berita yang jelas akan sumber infomrasinya, agar masyarakat tidak termakan akan hoax.

Akibat vitalnya, fungsi media di saat suasana tahun politik, calon pemimpin pun berusaha menjadikan media sebagai alat politik dalam meraup dukungan dengan menyampaikan informasi terkait dirinya. Dalam menyampaikan berita-berita media online, pasti memiliki metode atau teknik untuk menyusunya agar menjadi menarik yaitu biasanya dinamakan dengan framing. Ketika menjadi menarik, berita tersebut pun menjadi perhatian para pembaca sehingga para pembaca fokus dan terpengaruh oleh isi berita tersebut. Salah satunya yaitu mediaindonesia.com, mediaindonesia.com memiliki metode atau framing tersendiri agar khayalak tertarik untuk membaca beritaberita yang ada. Hal ini pun senda dengan apa yang di sampaikan oleh Henri Salomo Asisten Kepela Divisi mediaindonesia.com, yang mengatakan:

"Kita sih acuanya adalah kaidah jurnalistik, jadi kita bisa lihat apakah memuat berita sembarang? tidak, sumber berita nya juga jelas. Sistem konten yang di istilalhnya yaitu dok.mi, kita punya sumber ada dari aip, kosrenponden dan itu tersebar ada 40 daerah, media Indonesia tidak punya reporter jadi kita ambil dari metro tv, kan kita satu group, ada juga sumber dari mediaindonesia.com, disini semua dan pasti semua pengirim nya ada namanya di tertera di setiap berita, apalagi di pilpres kan banyak konten diwhatsap nah kita menghindari itu walaupun kita bisa mengunakan anonim-anonim itu tapi kita konfirmasi dulu atau konfrontasi dulu dengan narasumbernya. Jadi framing nya seperti apa, media Indonesia.com ini agak berbeda dengan medcom.id ataupun portal lain, jadi yang benar-benar portal itu mediaindonesia.com, mediaindonesia.com itu apa? Ya kita itu media Indonesia platform nya online jadi gaya bahasa, jadi kita mengacu pada media Indonesia. Cuma ada yang berbeda antara media yang online dan cetak, ada istilah dikampus itu namanya kalau di media cetak lebih tinggi ego nya, jadi apa yang menjadi headline besok adalah apa yang dipirkirkan oleh rapat redaksi, ketika online kita membuat berita langsung responya ada, kalau cetak minim 
sekali, apa yang hanya kita mau tidak juga, kita merubah sesuai dengan partisipasif lah dengan pembaca, kalau framing nya online lebih kearah meningatkan partisipasi, jadi kalau di istilahkan pembaca online ini merasa paling tau jadi ingin berkomentar ke semua berita yang menurut dia benar dan menurut dia salah, jadi kalau kita tidak masuk ke radar pembaca sih itu gak terlalu bagus." (Wawancara pribadi dilakukan pada tanggal 14 Februari 2020, Pukul 16.00 WIB).

Jika dilihat dari pernyataan Henri Salomo bahwa mediaindonesia.com dalam membuat berita dengan teknik framingnya, mediaindonesia.com dari dengan sumber informasi berita yang jelas, mediaindonesia.com juga cukup menarik karena beberapa beritanya yang menggambil dari Koran Media Indonesia, dan mediaindonesia.com membuat berita yang di sesuaikan selera pembaca agar langsung mendapatkan respon dari pembaca mendapatkan perhatian langsung dari pembaca.

Jika di perhatikan dalam beberapa pemberitaan terkait Pemilu, mediaindonesia.com ternyata ada strategi khusus karna dalam judul pemberitaanya hanya memberitakan terkait dengan calon Presiden nya saja dan tidak menyertai wakil Presiden, hal ini cukup unik, ketika media-media yang ada di seluruh Indonesia menyoroti juga wakil Presiden karena dianggap memiliki pengaruh dalam pemberitaan terkait pemilu. Hal ini pun dibenarkan oleh Henri Salomo Asisten Kepela Divisi mediaindonesia.com, yang mengatakan:

"Berita pilres yang kemaren, ketika kita perhatikan dan kita pertahakan yaitu ketika judul itu harus kita ambilnya kalau engga Jokowi ya Prabowo kalau cuman Sandiaga Ino sih masih kurang ya, jadi kita ambil angle yang menarik perhatian pembaca sih, kalau framing nya online lebih kearah meningatkan partisipasi" (Wawancara pribadi dilakukan pada tanggal 14 Februari 2020, Pukul 16.00 WIB).

Dilihat dari metode pemberitaan yang dilakukan oleh mediaindonesia. Secara tidak langsung juga memberikan dampak sehingga khalayak tertarik dan terfokus pada calon Presiden saja dan bukan wakil Presiden. Framing pemberitaan terhadap calon Presiden saja, secara tidak langsung melakukan personal branding terhadap calon Presiden saja tersebut. Dalam penelitian ini untuk melihat pengaruh media terhadap pasangan calon Presiden dalam pemberitaan sebagai upaya membranding dalam 
penelitian ini, dapat dilihat dari bagaimana mediaindonesia.com melakukan framing khusus dalam pemberitaan terkait Jokowi yang menyerang pribadi Prabowo. Seperti halnya perrnyataan oleh Henri Salomo Asisten Kepela Divisi mediaindonesia.com mengatakan :

"Jika kamu katakan lebih banyaknya atau lebih signifikanya pernyataan dari kubu Jokowi dibandingkan Prabowo di mediaindonesi.com, jadi reporter kita dilapangan tidak pernah terima di team mereka, kita cukup memberi ruang terhadap mereka, kalau tidak tidak mungkin ada berita terkait berita prabowo, kita tetap memuat berita terkait kubu mereka. Kita hanya menyampaikan fakta dalam pemberitaanya, tidak ada opini, kecuali opini dari orang terlibatnya sendiri." (Wawancara pribadi dilakukan pada tanggal 14 Februari 2020, Pukul 16.00 WIB).

Dari hasil wawancara diatas terlihat mediaindonesia.com melakukan personal branding tidak dilakukan dengan menggunakan opini sendiri melainkan dengan menggunakan pernyataan dari narasumber yang terkait, dalam hal hal mediaindonesia.com menyertakan ruang pernyataan yang lebih banyak dari pihak Jokowi dibandingkan dari kubu Prabowo, Dengan kata lain mediaindonesia.com melakukan personal branding dengan membentuk opini masyarakat dan mempengaruhi masyarakat dalam memilih kandidat calon Presiden. Seperti hal nya teori personal branding yang dikatakan dalam McNally \& Speak. yaitu ada tiga dimensi utama pembentuk personal branding dan itu digunakan oleh mediaindonesia.com dalam membranding Jokowi yaitu:

\section{Kompetensi atau kemampuan individu}

Untuk membangun reputasi atau personal branding, Jokowi harus memiliki sesuatu kemampuan khusus atau kompetensi dalam suatu bidang tertentu yang dikuasai, dalam studi kasus ini Jokowi dinilai memiliki kemampuan mensejahterahkan masyarakat dan membagi-bagi lahan gratis kepada masyarakat. Jokowi dapat 
membentuk sebuah personal branding melalui sebuah polesan dan metode framing yang disusun dengan baik mediaindonesia.com. Dengan begitu Jokowi digambarkan masyarakat sebagai soksok yang menaati aturan dalam debat kedua, profesionalitas dalam capaian kerja dan peduli kepada masyarakat. Hal tersebut mencerminkan nilainilai, kepribadian, keahlian, dan kualitas yang membuat Jokowi berbeda dengan yang lawan politiknya.

2. Style

Gaya merupakan kepribadian dari personal branding seseorang. Gaya merupakan bagian yang menjadikan diri Jokowi unik di dalam benak masyarakat. Gaya adalah cara Jokowi berhubungan dengan masyarakat. Seringkali kata-kata yang digunakan mediaindonesia.com untuk menilai gaya Jokowi mengandung suatu emosi yang kuat dan membuat simpati masyarakat.

\section{Standar}

Standar personal branding Jokowi sangat mempengaruhi cara orang lain memandang diri Jokowi sendiri. Standar akan menetapkan dan memberikan makna terhadap kekuatan personal branding. Namun kuncinya adalah Jokowi sendiri yang menetapkan standar, Jokowi sendiri yang harus melakukan. Dalam hal ini Jokowi melalui mediaindonesia.com menetapkan Jokowi standar yang terlalu tinggi dan terlanjur mengatakan pada orang lain bahwa Jokowi tidak menguasai lahan dan peduli kepada masyarakat.

Pandangan media terhadap suatu kasus pastinya mempengaruhi isi dari berita yang akan diangkat ke publik, karna apa yang dipandang oleh media benar akan lebih diangkat di setiap pemberitaanya, hal ini juga melihat bagaimana arah media tersebut apakah netral dalam berita tersebut atau justru memihak, akibat dari arah padangan berita yang diangkat pastinya akan mepengaruhi pembaca dengan opini yang dibangun dalam isi berita-berita tersebut, hal ini pun dapat dilihat dari pemberitaan dalam kasus Jokowi yang menyerang pribadi Prabowo di debat putaran kedua calon Presiden tahun 
2019. Seperti halnya pernyataan oleh Henri Salomo Asisten Kepela Divisi mediaindonesia.com mengatakan :

" Menurut saya itu bukan urusan privat, atau pribadi, kecuali misalnya dia mempertanyakan Prabowo jumatan dimana itu baru urusan privat, apalagi soal Hak Guna Usaha (HGU), saya sih tidak melihat privat atau menyerang personal. Memang dia terlihat menyindir prabowo soal kepemilikan lahan ya, ketika permasalahan lahan ini, aku tidak melihat dia menyerang pribadi sih, pertama ini di ungkapkan dalam area publik yaitu capres dan itu memang tanah milik negara, kecuali misalnya Jokowi menyindir statusnya cerai itu sih pribadi. Tapi memang hakikatnya debat ya debat menaikan positif saya dan menunjukan negative lawan, beda dengan kampanye itu visi-misi tapi ya walaupunn ada menyerang pribadi, ya aku si lihatnya tidak masalah privat. Misalnya ada berita di whatsapp-whatsapp itu terkait keluarga, itu sih privat, kita tidak kerana seperti itu, jadi ini sih netral menurut saya, saya sih lihat tidak terlalu adanya privat, kecuali yang dibilang Jokowi lahan Prabowo banyak padahal lahan prabowo hanya 1 hektar, Menurut saya masih normal, soal ini fakta, dan ini dibenarkan Prabowo". (Wawancara pribadi dilakukan pada tanggal 14 Februari 2020, Pukul 16.00 WIB).

Dari hasil wawancara diatas, Hal ini menguatkan realita bahwa mediaindonesia.com membuat opini publik terhadap Jokowi, yang memandang bahwa Jokowi tidak salah dengan tuduhan yang menyerang pribadi Prabowo, yang beralasan bahwa lahan yang dimiliki oleh Prabowo adalah Hak Guna Usaha (HGU) dan itu wajar karena dilakukan di area umum yaitu debat. Hal ini pun di kuatkan dengan alasan mediaindonesia.com memberitakan terkait hal ini karena mediaindonesia.com tidak masuk ke arena privat. Dan yang dilakukan Jokowi bukan lah menyerang hal privat.

Karena berita yang dipublikasikan bagi masyarakat merupakan hasil dari sebuah laporan suatu realita peristiwa yang terjadi dilapangan. Seharusnya mediaindonesia.com berusaha memberitakan kenyataan yang sebenarnya dan terlihat berimbang terhadap kedua belah pihak yang dilibatkan. Dari perumpamaan, frase yang menarik, mengaitkan bingkai dengan contoh, pemgambaran, gambar, sebab akibat, premis dasar, dan efek dari bingkai cenderung mereduksi pandangan lain dan lebih menonjolkan perspektif pihak Jokowi. Karena berita sebuah hasil laporan dari suatu peristiwa yang terjadi, seharusnya realitas media di publikasikan seperti kenyataan 
yang ada. Hal ini dapat dilakukan dengan menuliskan berita secara lengkap dengan sumber dan informasi secara berimbang.

\section{3 Hubungan Media dan Demokrasi}

Indonesia adalah suatu negara yang menganut sistem demokrasi, yang mana media menjadi salah satu pilar berjalanya suatu demokrasi atau tidak. Manakala media di dalam suatu negara, media mampu menjadi salah satu instrumen bagi adanya kebebasan berekspresi dan berpendapat, hal ini mengindikasikan bahwa negara tersebut bercorak demokratis. Dan justru sebaliknya, ketika media di negara tersebut tidak bisa menjadi instrumen bagi kebebasan berekspresi dan berpendapat, apalagi selalu berada di bawah kontrol oleh seorang penguasa, maka ini mengindikasikan bahwa suatu negara tidak demokratis (Kacung Marijan: 281-282). Sistem negara yang demokratis membuat media menjadi lebih bebas dan tidak dikendalikan lagi oleh pemerintahan, akibat dari kebebasan yang dimiliki media saaat ini, membuat media menjadi tidak terkontrol, hal ini membuat media online kini seperti dalam kasus mediaindonesia.com tidak terkontrol dalam memeroses berita-berita untuk dipublikasikan.

Patut diketahui bahwa media memiliki pengaruh, baik kepada masyarakat maupun kepada pemerintah. Sebagai mana mediaindonesia.com yang dalam kasus ini juga sebagai salah satu media online dapat memengaruhi karena lebih fokus pada isuisu tertentu dan bukan yang lain. Dalam hal ini, mediaindonesia lebih fokus terhadap pemberitaan Jokowi dalam menyelesaikan masalah yang dituduhkan kepada nya terkait penyerangan pribadi yang dilakukanya kepada Prabowo, dan juga lebih fokus terhadap Prabowo dalam hal menekankan penguasaan lahan yang dimiliki nya di Kalimantan dan Aceh yang dinilai telah melakukan ketimpangan terhadap rakyat kecil.

Dalam penelitian ini, jika bandingkan dua fungsi yang harus dijalankan oleh media dengan apa yang dilakukan oleh mediaindonesia.com, dapat diketahui bahwa Pertama, mediaindonesiacom dalam menyediakan ulasan terkait Jokowi dan Prabowo yang ingin berkuasa sebagai Presiden di Indonesia justru tidak cermat dengan 
ulasannya menitik berat kan keberpihakan yang justru berbanding terbalik sebagai peran dari pengawas. Dan Kedua, mediaindonesia.com seharusnya menyediakan informasi yang dapat dipercaya mengenai isu sosial dan politik yang penting setiap hari, justru dalam kenyataanya pemberitaan yang dilakukan oleh mediaindonesia.com tidak menyediakan pemberitaanya yang condong kebanyakan menekankan sisi negatife dari Prabowo dan sisi positif dari Jokowi, serta narasumber yang terdapat didalam pemberitaanya dominan dikuasai oleh kubu dari Jokowi.

Independensi media merupakan salah satu prasyarat agar media mampu mainkan peran pentingnya dalam demokratisasi (Gati, 2016:55). Dari kasus ini, dapat tergambarkan bagaimana mediaindonesia.com memainkan peran pentingnya. Dari keindependensiannya, suatu media membuat media terhindar dari kecenderungan informasi dan pemberitaan. Namun cukup disayangkan karena indepedensi media yang ada di Indonesia memprihatinkan. Jika dibandingkan dengan zaman orde lama dan orde baru, intervensi dan pengaruh yang besar terhadap media kebanyakan dari pemerintah. Tetapi di zaman sekarang justru para pemilik media yang kebanyakan menjadi para politisi. Kini independensi pers sebagai salah satu pilar demokrasi yang menjadi media harapan rakyat untuk mendapatkan kebenaran kini sudah mulai pudar akibat kepentingan para pemilik media yang menguasai. Yang mana semakin tergerusnya informasi publik dan besarnya pengaruh para pemilik modal atau kepentingan politik dalam suatu media membuat terciptanya hegemoni politik yang mengancam berjalanya proses demokratisasi.

\section{KESIMPULAN}

Berdasarkan hasil pemaparan penulis di atas, mengenai analisis framing terkait pemberitaan jokowi yang menyerang pribadi prabowo pada debat calon presiden putaran kedua tahun 2019 dalam "mediaindonesia.com" dalam mediaindonesia.com dapat diambil kesimpulan sebagai berikut: 
Pada pemberitaan-pemberitaan yang ada terdapat kontruksi realitas yang dilakukan media mediaindonesia.com menjadikan peristiwa atau masalah tersebut terlihat menarik dan membuat penasaran. Hal dapat dilihat dari bagaimana yang dilakukan mediaindonesia.com dalam memberitakan "Jokowi menyerang pribadi Prabowo terkait penguasaan lahan di debat kedua pemilihan Presiden”. Yang secara terus-menerus dengan menekankan sudut pandang dan membuat berita ini menjadi berita utama. Adapun sudut pandang yang ditekankan oleh mediaindonesia.com yaitu mengenai perkataan Jokowi yang menyerang Prabowo dan Kepemilikan lahan yang dimiliki Prabowo.

Dalam dari beberapa berita yang di hadirkan oleh mediaindonesia.com terlihat jelas bahwasanya mediaindonesia.com membuat citra politik Jokowi semakin bagus dan positif di pandangan khayalak dan menunjukan citra negetiv terhadap Prabowo . Ini bisa dilihat dari hasil analisis framing dari beberapa yang dihadirkan, secara konsisten mediaindonesia.com membuat berita secara berturut-turut memihak kepada Jokowi, pandangan politik yang dimulai dari pemilihan judul pada suatu berita hingga opini yang dibangun terhadap publik. Dalam pemberitaan mediaindonesia.com menekankan pada hal yang mendukung terhadap Jokowi dan menunjukan sudut pandang yang mengarah pada penguasaan lahan yang dimiliki Prabowo.

Keberpihakan mediaindonesia.com ini mendukung mulai pudarnya nilai demokrasi di Indonesia yang dimana media sebagai pilar ke empat dari demokrasi itu sendiri. Kebebasan media dari Pers nasional berperan mengembangkan pendapat umum berdasarkan informasi yang tepat, akurat dan benar. Bahkan sebagai pilar keempat dari demokrasi, media seharusnya memiliki hak kritik, hak control dan hak koreksi.

Dengan cara itu media dapat menjadi penjaga, pemantau, dan pengontrol terhadap jalanya pemerintahan yang baik dan bersih dan pelaksanaan demokrasi bukan justru keberpihakan dan menghilangkan peran dari pers yang sesungguhnya. Dalam hal 
ini media memiliki peran yang yang cukup penting bagi warga negara demokrasi seperti Indonesia saat ini.

Tidak bisa dipungkiri bahwa kemampuanya yang dimiliki oleh media dapat mempengaruhi terjadinya perubahan sikap dan perilaku masyarakat dalam proses demokratisasi. Harusnya mediaindonesia.com menyadari pengaruh yang dimiliki nya sangat besar dalam keberlangsungan masyarakat dan demokrasi di Indonesia. Harus di ingat dalam kondisi dimana terdapat kebebasan arus informasi dan gagasan, maka kritik dan control terhadap penyelengara negara, mediaindonesia.com seharusnya mampu melaksanakan fungsinya sebagai peringatan terhadap penyimpangan yang terjadi di Indonesia.

\section{DAFTAR PUSTAKA}

Albi Anggito \& Johan Setiawan,S.Pd, 2018 "Metode Penelitian Kualitatif", Jawa Barat, Cv Jejak. 
Dr. Heri Budianto, M.Si,2018 "Media, Dan Komunikasi Politik”, Yogyakarta: Mbridge Press.

Dewi Haroen,2014 “Personal Branding” Jakarta: Pt Gramedia Pusaka Utama.

Eriyanto,2002,"Analisis Framing” Yogyakarta:Lkis.

Georg Sorensen, 2003, Demokrasi And Demokratization: Processed And Prospects In A Changing Word, Trj. I. Made Krisna, Demokrasi Dan Demokratisasi (Proses Dan Prospek Dalam Sebuah Dunia Yang Sedang Berubah, Yogyakarta : Pustaka Pelajar.

Hm, Nasruddin Anshoriy Ch, 2008, "Bangsa Gagal Mencari Identitas Kebangsaan”Yoyakarta: Lkis.

Ibnu Ahman, 2004“Konstruksi Realitas Politik Dalam Media Massa” Jakarta:Granit.

John Nichols, Dan Mcchesney,"Tragedi \& Lelucon: Bagaimana Media Amreika Menjual Peran, Memutar Pemilihan Dan Menghancurkan Demokrasi.” New York: New Press.

Mcnally, D., \& Speak, K. D. (2002). Be Your Own Brand.San Fransisco: Berret Koehler Publisher

Mulyana, Deddy. 2006. "Metodologi Penelitian Kualitatif". Bandung : Pt Remaja Rosdakarya

Muhtar Haboddin,2019,'Pemilu Dan Partai Politik Di Indonesia” Malang :Ub Press.

Nazir, Muhammad.1986. "Metode Penelitian”, Bandung: Remaja Rosdakarya

Sujinah, 2017, “Menjadi Pembicara Terampil”, Yogyakarta :Cv Budi Utama.

Trianto, (2007). Model-Model Pembelajaran Iinovatif Berorientasi Kontruktivistik. Prestasi Pustaka: Jakarta.

86 
Dr.Abd, Muid N., Ma. (2013), “Arah Baru Demokrasi Indonesia”, Jakarta:Lecture Publisher.

Afdhal Anasrul,2019,"Analisis Wacana Pemberitaan Pidato Tampang Boyolali Oleh Prabowo Subianto Di Media Online Mediaindonesia.Com” Universitas Islam Negeri Sultan Syarif Kasim Riau

Gita Gayatri,Akses Informasi Publik Dan Peran Media Dalam Demokrasi,Jurnal Dewan Pers,Edisi 12,2016

Kamaruddinhasan, Kajian Netralitas Industri Media Dalam Pemilu 2014 Vol. Xii No. 1 April 2014

Dr.I Putu Ari Astawa, 2017, ’Demkrasi Indonesia’Universitas Udayan.

\section{Website:}

https://nasional.kompas.com/read/2019/03/30/10015611/ini-segmentasi-dan-aturandebat-capres-malam-nanti?page=all (diakses pada tanggal 20/1/2020 pukul 13.10 WIB).

https://tirto.id/dianggap-serang-pribadi-prabowo-jokowi-dilaporkan-ke-bawaslu-dhiP (diakses pada tanggal 21/1/2020 pukul 15:07 WIB)

https://mediaindonesia.com/read/detail/288644-media-indonesia-raih-penghargaansurat-kabar-nasional-terbaik, diakses pada tanggal 29 februari 2020, pukul 13:15 WIB).

https://mediaindonesia.com/read/detail/256151-kapolri-serahkan-piagam-

penghargaan-untuk-media-indonesia, (diakses pada tanggal 29 februari 2020, pukul 13:15 WIB).

https://mediaindonesia.com/statics/tentang-kami, (diakses pada tanggal 29 februari 2020, pukul 18:15 WIB). 
https://mediaindonesia.com/read/detail/218458-relawan-jokowi-tidak-menyerangpribadi-prabowo, ( diakses pada 10 Januari 2020 pukul 13:00 WIB)

https://mediaindonesia.com/read/detail/217604-jokowi-kian-meyakinkan, (diakses pada 10 Januari 2020 pukul 13:10 WIB)

https://mediaindonesia.com/read/detail/217744-kepemilikan-lahan-luas-cerminkanketimpangan.html, (diakses pada 10 Januari 2020 pukul 13:20 WIB

https://mediaindonesia.com/read/detail/217956-priyo-pelaporan-jokowi-bukan-untukpidana, (diakses pada 10 Januari 2020 pukul 14:11 WIB)

http://hukum.unsrat.ac.id/uu/uu_40_99.htm, diakses pada 6 Maret 2020, Pukul 13.00 WIB) 